\title{
Gryospheric data for model validations: requirements and status
}

\author{
R. G. BARry \\ National Snow and Ice Data Center, Cooperative Institute for Research in Environmental Sciences, University of Colorado, \\ Campus Box 449, Boulder, CO 80309-0449, U.S.A.
}

\begin{abstract}
The general status of cryospheric datasets required in climate model studies is reviewed. Datasets are necessary as boundary conditions, and for validation purposes. The former application is decreasing as cryospheric variables are increasingly being derived prognostically. By contrast, the scope of cryospheric parameters that can be validated is expanding. Cryospheric datasets suitable for validation studies are reported and areas where data are lacking are identified.
\end{abstract}

\section{INTRODUGTION}

Numerical climate models require certain global data as boundary conditions. In the first phase of climate modelling using atmospheric general circulation models (ACGMs) in the 1970 s, climate experiments generally involved a modern "control" run and a perturbation experiment, analyzing the model's equilibrium response to some change in boundary conditions or model physics. The latter might include a dry atmosphere, prescribed vs prognostic clouds, or varying lapse-rate parameterization. The former category included changing continental geography (Barron and others, 1980), incorporating ice sheets, introducing a stratospheric volcanicaerosol layer, modifying sea-ice limits or land-surface cover, and albedo (Barry, 1975). First generation AGCMs were used by several groups to perform experiments with ice age boundary conditions (Williams and others, 1974; Gates, 1976; Manabe and Hahn, 1977). These studies involved the development of maps with changed continental boundaries, land and sea-ice extent, sea-surface temperatures and surface albedo. The CLIMAP project for the Last Glacial Maximum and the COHMAP project for conditions between 18000 years BP and present, at 3000 year intervals, are important examples of such boundary-condition mapping programs for model input purposes. In parallel with these attempts at the reconstruction of specific paleoclimates, the effects on the atmosphere of imposed changes in the extent of snow cover (Williams, 1975) and of sea ice (Herman and Johnson, 1978) were simulated.

The second generation of GCMs from the mid 1980s generally incorporated higher-resolution and improved model physics. They could treat atmosphere-ocean interactions, for example (Meehl, 1992); the representation of ocean processes ranges from a simple "swamp" ocean, with no heat storage or ocean currents, to a "slab" mixed-layer ocean where sea-surface temperatures are determined from the surface-energy balance and heat storage, or a coupled ocean GCM that incorporates energy transfers and ocean dynamics (Manabe and others, 1992).

There is an extensive literature on the use of coupled atmospheric swamp-ocean and slab-ocean mixed-layer models for climate sensitivity studies. This second phase of GCM developments also witnessed the beginning of transient experiments, for 100 years or more, in genuine climatechange studies of increasing greenhouse-gas concentrations. Second-generation model studies that address the cryosphere are primarily experiments to assess $\mathrm{CO}_{2}$ doubling sensitivity, where it rapidly becomes evident that thermodynamic and dynamic processes need to be treated, and that many variables, other than surface albedo, require parameterization (Meehl and Washington, 1990). Specific studies of the importance of cryospheric parameterizations were also performed, particularly in view of the role of snowand ice-albedo feedbacks in climate sensitivity to forcing (Ingram and others, 1989; Oglesby, 1990; Cohen and Rind, 1991).

The third generation of fully coupled GCMs are beginning to link the atmosphere-ocean-cryosphere terrestrial biosphere in fully-coupled treatments Broccoli and Manabe, 1993), and to incorporate biogeochemical transfers. Land-surface schemes are being intercompared (Henderson-Sellers and others, 1993), but so far similar work for the cryospheric variables is lacking. Nesting of high-resolution mesoscale models in an atmospheric GCM is increasingly used to address regional processes, including orographic precipitation (Giorgi and others, 1993) and marginal seaice zone processes (Walsh and others, 1993; Lynch and others, 1995).

A further development is the improved parameterization of variables such as snow and ice albedo in both process models (Ebert and Curry, 1993) and in GCMs (Barry, 1996), as well as the detailed treatment of ice dynamics in sea-ice models, including leads, ridging and ice drift (Hibler and Flato, 1992; Mellor and Häkkinen, 1994). There are GCM sensitivity studies that update earlier analyses for the effects of leads (Vavrus, 1995), and sea-ice extent and thickness (Rind and others, 1995). These illustrate the increasing need for cryospheric data and highlight the gaps in current archives (Table 1). 


\begin{tabular}{|c|c|c|c|c|}
\hline Variable & Frequency & Source & Availability & Scale \\
\hline Extent/concentration type & Monthly & Compilation (J.Walsh) & $\begin{array}{l}\text { Northern Hemisphere 1901-90 } \\
\text { Southern Hemisphere } 1973-90\end{array}$ & $1 \times 1$ grid \\
\hline Extent/concentration type & Weekly & $\begin{array}{l}\text { AVHRR, SSM/I, } \\
\text { and airborne }\end{array}$ & $\begin{array}{l}\text { Northern Hemisphere 1973-90 } \\
\text { Southern Hemisphere 1973-90 }\end{array}$ & $\begin{array}{l}1: 11.6 \mathrm{M}\left(0.25^{\circ} \text { grid }\right) \\
1: 16 \mathrm{M}\end{array}$ \\
\hline Extent/concentration type & 2 day & SMMR & Bi-polar $10.78-08.87$ & $25 \times 25 \mathrm{~km}$ grid \\
\hline Thickness & Climatology & Sonar (submarine/moored) & Arctic & (Point or track) \\
\hline Snowmelt onset & Date of occurrence & SMMR, SSM/I & Arctic (research) 1978 present & $25 \times 25 \mathrm{~km}$ grid \\
\hline Polar surface albedo & Daily & AVHRR & Planned Pathfinder Product 1982-97 & $5 \mathrm{~km}, 25 \mathrm{~km}$ \\
\hline
\end{tabular}

\section{DATA REQUIREMENTS}

Requirements for cryospheric data have recently begun to receive attention from several standpoints. In 1980, the Snow Watch Group identified the requirements for GCMs in terms of basic global maps of snow and ice extent, which until then were mostly in map form, or in the case of snowdepth climatology were thought to be unavailable (Hahn, 1981). Reports of the World Climate Programme (Jenne, 1982) set out basic data required for model verification and process studies, and these have been subsequently considerably refined and expanded (see Crane, 1993; WMO/Unesco/ UNEP/ICSU, 1995). A comparable effort focusing on modelling needs is desirable (see recommendations in Barry and others, 1993), but is beyond the scope of this paper.

\section{CRYOSPHERIC DATASETS}

The primary emphasis here is on hemispheric or global datasets that are available digitally and in gridded form, suitable for use in validation of GCM outputs. However, important gaps in information needed for process model studies and model parameterization are also discussed. Tables 1-3 summarize key cryospheric sets of interest to modellers for sea ice, snow cover and land ice, respectively. Before discussing these, it should be noted that a weekly Northern Hemisphere combined snow-cover and sea-ice extent product for 1978-95 is now available on CD-ROM from National Snow and Ice Data Center (NSIDC, 1996a). It incorporates the National Oceanic and Atmospheric Administration National Environmental Satellite Data Information Service (NOAA-NESDIS) weekly snow data, regridded to the Equal Area Special Sensor Microwave Imager (SSM/I) Earth (EASE) grid (Armstrong and Brodzik, 1995), combined with the Scanning Multichannel Micro- wave Radiometer (SSMR) and SSM/I-derived weekly averaged ice extent.

\section{Snow cover}

Data on weekly snow-cover extent (see Table 2) are available for the Northern Hemisphere since 1966, based on satellite visible and infrared imagery, but more reliably since 1972 when the Advanced Very High Resolution Radiometer (AVHRR) was first launched. These data do not take account of snow on sea ice or Greenland. There is a limited dataset for South America for 1974-80, the only southern continent with significant snow cover. These NOAANESDIS products are, unfortunately, gridded to a polar stereographic $89 \times 89$ square cell grid, so that the resolution is variable; also a grid is counted as snow covered if the fractional cover is $\geq 50 \%$. New products on snow extent that are planned to be available in 1998 on a daily or weekly basis are described in Hall (1995). A passive-microwavederived six day (five day) snow-extent product based on the SMMR for 1978-87 (SSM/I for 1987-present) with $25 \times 25 \mathrm{~km}$ gridcells is currently in preparation at NSIDC.

Snow water equivalent (SWE) can be estimated from passive-microwave data and an experimental mid-monthly dataset was generated for 1978-87 by Chang and others (1990). The data have recently been compared with the output of six GCMs (Foster and others, 1996) based on Atmospheric Model Intercomparison Project standard control runs for 1979-88 (Gates, 1992). However, Tait and Armstrong (1996) find systematic biases in products obtained with the linear algorithm developed by Chang and others (1990) compared with station measurements. It is clear that spatio-temporal adjustments are necessary in such algorithms to rectify errors caused by topographic effects on SWE values, screening by forest canopies, and the occur-

Table 2. Global snow-cover variables and their availability

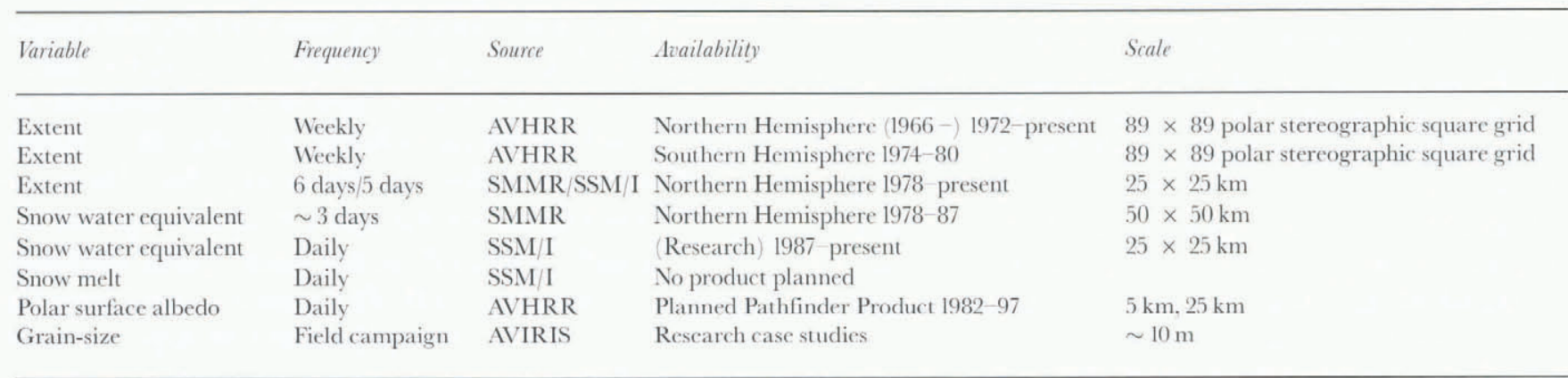




\begin{tabular}{|c|c|c|c|}
\hline Variable & Source & Availability & Scale \\
\hline Extent (land ice) & $\begin{array}{l}\text { World Atlas of Snow and Ice Resources, } \\
\text { Institute of Geography, Moscow }\end{array}$ & 1998 Digital product planned & $1: 1.5-1: 3$ million maps \\
\hline $\begin{array}{l}\text { Elevation grids (Greenland, } \\
\text { Antarctica) }\end{array}$ & Radar altimetry & To $81.5^{\circ}$ lat. & $5 \mathrm{~km}$ horizontal resolution \\
\hline Glacier inventory & WGMS, WDC-A for Glaciology & Former Soviet Union, parts of China & \\
\hline Permafrost extent & International Permafrost Association & Northern Hemisphere 1997 & 1:10 M map; digitized \\
\hline Permafrost thickness & International Permafrost Association & Northern Hemisphere 1997 & 1:10 M map: digitized \\
\hline
\end{tabular}

rence of depth hoar or melt on snow-grain surfaces. Nevertheless, the work of Goodison (1989) for the Canadian Prairies illustrates the potential of passive-microwave sensors, even for operational products. Walker and Goodison (1993) have also demonstrated that snowmelt signatures are readily detectable with passive-microwave data although this approach has not yet been implemented as a hemispheric analysis product.

For validation purposes, station data are often desirable, but until now these have been mostly climatological averages. Newly available regional datasets include CDROMs of daily snow depth at 284 stations in the Former Soviet Union (FSU) from the beginning of observations (NSIDC, 1994) and snow depths at North Pole drifting stations, 1937-38 and 1951-91 (NSIDC, 1996b). Additionally, 10 day snow-course surveys for more than 1300 stations across the FSU for 1966-90 have been received and are currently being quality checked prior to release.

Snow (and ice) albedo is an important model variable that is commonly parameterized. Approaches to this range from simplistic temperature dependencies (linear or step functions), to calculations that take account of snow age, fractional cover, vegetation masking depth, grain-size, solar zenith angle and spectral range. (see Barry, 1996). The AVHRR Polar Pathfinder plans to generate polar surface broadband albedo data products over the next two to three years (Polar Pathfinder Group, 1997). Research on the estimation of snow grain-size via a pixel mixing approach is being carried out using Airborne Visible and Infrared Imaging Spectroradiometer (AVIRIS) data over mountain watersheds (Nolin and Dozier, 1993) but wide-area implementation of this approach is unlikely in the near future.

\section{Sea ice}

Twenty-five years of data on sea-ice extent and concentration for both polar regions are available on a weekly basis since 1972-73 and daily since 1987 (Table 1). These have also been reformatted for use by the European Centre for Medium-Range Forecasts (ECMWF) model re-analysis program (Nomura, 1995). For the northern polar regions, monthly ice extent and concentration data exist since 1953, and these data will be improved retrospectively as 10 day Russian data for the summer period are incorporated. Since 1900 there are also monthly extent data, mainly for the North Atlantic sector, that are less reliable and more spatially heterogeneous.

Currently there are only limited climatological icethickness maps for the Arctic Ocean (Bourke and McLaren, 1992), and no digital archive. There are also extensive pub- lished thickness-frequency data for the Arctic and more limited publications for the Antarctic. An atlas of morphological characteristics in the Arctic Ocean exists in digital form (Romanov, 1993), although information on snow cover on the ice is limited, and those are only point or limited-area data on melt-pond coverage. Melt onset dates can be estimated from passive-microwave signatures, and work is in progress to provide a dataset for 1978-present. There are also limited data on lead coverage (Lindsay and Rothrock, 1995).

Ice surface albedo has been mapped in the Arctic for 10 summer seasons using visible satellite images classified subjectively, as well through analyses of radiance data. However, averages for individual months are currently only within about \pm 0.10 (Schweiger and others, 1993). Techniques are available to estimate ice surface temperature from infrared radiance data and products for broadband surface albedo, ice surface temperature and a cloud mask will be generated by the AVHRR Polar Pathfinder for 1982-97 (Polar Pathfinder Group, 1997). In addition, the TIROS Operational Vertical Sounder (TOVS) Polar Pathfinder will provide daily and monthly gridded products of surface skin-temperature and boundary-layer parameters for 1979 97. The EOS Polar Exchange at the Sea Surface (POLES) project also plans to produce products of sea-ice statistics from MODIS and Radarsat data Rothrock and others, 1995).

\section{Land ice}

Remarkably, the state of information on basic land-ice parameters is the least satisfactory (Table 3). There is currently no digital archive of land-ice extent and elevation. Even inventory data on glaciers are unavailable for several countries with large ice areas, including Canada (Barry, 1995) and the Himalayan nations, although partial national archives exist. In other areas, such as China and South America, satellite mapping is in progress. Data on surface elevation for the Greenland and Antarctic ice sheets poleward to 81.5 latitude are available from satellite radar altimetry collected by ERS-1 and ERS-2. In 1998 the Radarsat Antarctic Mapping Program will collect data for the first complete high-resolution digital map of all of Antarctica (Polar Pathfinder Group, 1997).

Future plans include the precision mapping of Greenland and Antarctica by the EOS Geoscience Laser Altimeter System (GLAS) in about 2002 and the mapping of selected target glaciers via the Advanced Spaceborne Thermal Emission and Reflection Radiometer (ASTER), 
in conjunction with a proposed Global Land Ice Monitoring with Satellites (GLIMS) (Kargel and Kieffer, 1995).

Data on general ground ice and frozen ground conditions are currently not available in digital form, although a digital version of a Northern Hemisphere map of perennially frozen ground (Brown and others, in press) is in preparation. Under the auspices of the International Permafrost Association, a project to develop a Global Geocryological Database is currently in progress and a CDROM is planned for release in mid 1998 (Barry and others, 1995).

\section{CONCLUDING REMARKS}

Data products characterizing many large-scale properties of the cryosphere, and suitable for the validation of GCM control experiments, are now available. Notable gaps exist for land-ice extent and frozen ground characteristics, although such products are planned, or are in preparation. In the case of the seasonally varying elements (snow cover and sea ice), time series of their extent are available individually, or combined. The weekly $25 \times 25 \mathrm{~km}$ combined snow-cover and sea-ice dataset (17 years) for the Northern Hemisphere should be especially valuable for climate model validation. However, for snow depth (water equivalent) and ice thickness, even reliable climatologies remain to be developed. Intercomparisons of NOAA visible-based and NASA passive-microwave derived snow extent by Robinson (1997) and Armstrong (personal communication from R. L. Armstrong, 1996) show significant discrepancies. Whether these exhibit systematic spatial and temporal biases remains to be determined. Nevertheless, further improvement in this situation can be expected over the next few years as blended satellite and ground data on SWE are produced and newly released in situ ice-thickness measurements become available for the Arctic Ocean. It is in the area of derived parameters (such as albedo and snow grain-size) that much additional work remains to be done. There is also a significant need for readily accessible test data for process model validation in all areas of cryospheric research. An illustration of what is currently available is provided by the holdings of the National Science Foundation's Arctic System Science (ARCSS) Data Coordination Center at the National Snow and Ice Data Center (McGinnis and Cross, 1997) and accessible via the World Wide Web.

\section{ACKNOWLEDGEMENTS}

Supported in part by University of Washington (POLES) subcontract to the University of Colorado. Thanks are due to L. Ryder for word processing.

\section{REFERENCES}

Armstrong, R. L. and M. J. Brodzik. 1995. An carth-gridded SSM/I data set for cryospheric studies and global change monitoring. Adv. Space Res., $15(10), 155-163$.

Barron, E. J., J. L. Sloan and C. G. A. Harrison. 1980. Potential significance of land - sea distribution and surface albedo variations as a climatic forcing factor. 180 M.Y. to the present. Palaeogeogr, Palaeoclimatol., Palaeoecol., $30(1), 17-40$.

Barry, R. G. 1975. Climate models in palaeoclimatic reconstruction. Palaeogeogr., Palaeoclimatol., Palaeoecol., 17 (2), 123-137.

Barry, R. G. 1995. Observing systems and data sets related to the cryosphere in Canada: a contribution to planning for the Global Climate Obser- ving System. Atmosphere-Ocean, 33 4), $771-807$.

Barry, R. G. 1996. The parameterization of surface albedo for sea ice and its snow cover. Prog. Phys, Geogr., 20 1), 63-79.

Barry, R. G., B. E. Goodison and E. F. LeDrew, eds. 1993. Snow Watch' 92. Detection Strategies for Snow and Ice: Proceedings, International Workshop on Snow and Lake Ice Cover and the Climate System, 29 March-1 April 1992, Niagara-on-the-Lake, Ontario. Glaciol. Data Rep. GD-25.

Barry, R. G., J. A. Heginbottom and J. Brown. 1995. Workshop on Permafrost Data Rescue and Access, 3-5 November 1994, Oslo, Norway. Glaciol. Data Rep. GD-28.

Bourke, R. H. and A. S. McLaren. 1992. Contour mapping of Arctic Basin ice draft and roughness parameters. f. Geophys. Res., 97 (C11), 17,715 17,728 .

Broccoli, A. J. and S. Manabe. 1993. Climate model studies of interactions between ice sheets and the atmosphere ocean system. In Peltier, W.R., ed. Ice in the climate system. Berlin, etc., Springer-Verlag, 271-290. (NATO ASI Series I: Global Environmental Change 12.

Brown, J., O. J. Ferrians, Jr, J. A. Heginbottom and E. S. Melnikov, eds. In press. Circumarctic map of permafrosl and ground ice conditions. Reston, VA, U.S. Geological Survey. (CP 45, Scale 1: 10 million.)

Chang, A. T. C., J. L. Foster, D. K. Hall, H.W. Powell and Y. L. Chien. 1990. Nimbus-7 derived global snow cover and snow depth data set: the pilot land data system. Greenbelt, MD, National Aeronautics and Space Administration. Goddard Space Flight Center.

Cohen, J. and D. Rind. 1991. The effect of snow cover on the climate. $\hat{j}$. Climate, 4 7), $689-706$.

Crane, R. G. 1993. Workshop on cryospheric data rescue and access. Glaciolog. Data GD-25, 274-294.

Ebert, E. E. and J. A. Curry. 1993. An intermediate one-dimensional thermodynamic sea ice model for investigating ice atmosphere interactions. f. Geophys. Res., 98 (C6), 10,085-10,109.

Foster, J. L. and 9 others. 1996. Snow cover and snow mass intercomparisons of general circulation model and remotely sensed datasets. f. Climate, 9 $2,409-426$.

Gates, W. L. 1976. Modeling the ice age climate. Science, 191 (4232), 1138-1144.

Gates, W. L. 1992. AMIP: the Atmospheric Model Intercomparison Project. Bull. Am. Meteorol. Soc., 73 12, 1962-1970.

Giorgi, F., G. T. Bates and S.J. Nieman. 1993. The multiyear surface climatology of a regional atmospheric model over the western United States. J. Climate, $6(1), 75-85$.

Goodison, B. E. 1989. Determination of areal snow water equivalent on the Canadian prairies using passive microwave satellite data. In International Geoscience and Remote Sensing Symposium (IGARSS). Quantitative remote sensing: an economic tool for the nineties. 12th Canadian Symposium on Remote Sensing, Vancouver, British Columbia, 10-14 July 1989. Proceedings. Vol. 3. New York, Institute of Electrical and Electronics Engineers, 1243-1246.

Hahn, D. G. 1981. Summary requirements of GCMs for observed snow and ice cover data. Glaciol. Data GD-11, 43-53.

Hall, D. K. 1995. First Moderate Resolution Imaging Spectroradiometer (MODIS) Snow and Ice Workshop. NASA-Conf. Publ. CP 3318.

Henderson-Sellers, A., A. -L. Yang and R. E. Dickinson. 1993. The project for intercomparison of land-surface parameterization schemes. Bull. Am. Meteorol. Soc, $74(7), 1335-1349$.

Herman, G. F. and W.T. Johnson. 1978. The sensitivity of the general circulation to Arctic sea ice boundaries: a numerical experiment. Mon. Weather Rev., 106 (12), 1649-1664.

Hibler, W. D., III and G. M. Flato. 1992. Sea ice models. In Trenberth, K. E., ed. Climate system modeling. Cambridge, Cambridge University Press, 413 436.

Ingram, W. J., C. A. Wilson and J. F. B. Mitchell. 1989. Modeling climate change: an assessment of sea ice and surface albedo feedbacks. J. Geophys. Res., $94(\mathrm{D} 6), 86098622$.

Jenne, R. L. 1982. Planning guidance for the world climate data system. Geneva, World Meteorological Organization. World Climate Programme. (WCP 19.)

Kargel. J. S. and H. H. Kieffer. 1995. Opportunity for nearly comprehensive global glacier monitoring with ASTER. [Abstract.] EOS, 76(46), Fall Meeting Supplement, F91.

Lindsay, R. W. and D. A. Rothrock. 1995. Arctic sea ice leads from advanced very high resolution radiometer images. 7. Geophys. Res., 100 (C3), 4533 4544 .

Lvnch, A. H., W. L. Chapman, J. E. Walsh and G. Weller. 1995. Development of a regional climate model of the western Arctic. J. Climate, 8 (6), 1555 1570 .

Manabe, S. and D. C. Hahn. 1977. Simulation of the tropical climate of an ice age. J. Geophys. Res., 82(27), 3889-3911.

Manabe, S., M. J. Spelman and R. J. Stouffer. 1992. Transient responses of a coupled ocean-atmosphere model to gradual changes of atmospheric 
$\mathrm{CO}_{2}$. Part II: Seasonal response. 7. Climate, 5 2, 105- 126.

MeGinnis, D. L. and M. D. Cross. 1997. Arctic modeling data resources: the data archives at the ARCSS Data Coordination Center and the National Snow and Ice Data Center, U.S.A. Ann. Glaciol., 25 (see paper in this volume.

Meehl, G. A. 1992. Global coupled models: atmosphere, ocean, sea ice. In Trenberth, K. E., ed. Climate system modeling. Cambridge, Cambridge University Press, 555-581.

Meehl, G. A. and W. M. Washington. 1990. CO, climate sensitivity and snow sea-ice albedo parameterizations in an atmospheric GCM coupled to a mixed-layer ocean. Climatic Change, 16 (3), 283-306.

Mellor, G. L. and S. Häkkinen. 1994. A review of coupled ice ocean models. In Johannessen, O. M., R. D. Muench and J. E. Overland, eds. The polar oceans and their role in shaping the global environment: the Nansen Centennial volume. Washington, DC; American Geophysical Union, 21-31. Gcophysical Monograph 85.)

National Snow and Ice Data Center (NSIDC). 1994. Historical Soviet daily snow depth. Boulder, CO, University of Colorado. Cooperative Institute for Research in Environmental Sciences. National Snow and Ice Data Center.

National Snow and Ice Data Center (NSIDC). 1996a. Norlhern Hemisphere EASE-grid weekly snow cover and weekly extenı. Vol. I.0, 2.0. Boulder, CO, University of Colorado. Cooperative Institute for Research in Environmental Sciences. National Snow and Ice Data Center.

National Snow and Ice Data Center (NSIDC). 1996b. Arclic Ocean snow and meteorological observations from drifting stations. Boulder, CO, University of Colorado. Cooperative Institute for Research in Environmental Sciences, National Snow and Ice Data Center.

Nolin, A.W. and J. Dozier. 1993. Estimating snow grain size using AVIRIS data. Remote Sensing Environ., 44 (2-3), 231-238.

Nomura, A. 1995. Global sea ice concentration data set for use with the EC.MIVFreanalysis system. Reading, European Centre for Medium-Range Weather Forecasts. Re-Analysis Project (ERA). (Technical Report 76. .

Oglesby, R.J. 1990. Sensitivity of glaciation to initial snow cover, CO2, snow albedo, and oceanic roughness in the NCAR CCM. Climate Dyn., 4(4), 219-235.
Polar Pathfinder Group. 1997. Satellite-derived data produced for the polar regions. EOS, 78 5), 52. (EOS Electronic Supplement 96149e.)

Rind, D., R. Healy, C. Parkinson and D. Martinson. 1995. The role of sea ice in $2 \times \mathrm{CO}_{2}$ climate model sensitivity. Part I: The total influence of seaice thickness and extent. 7. Climate, 8 3, 449-463.

Robinson, D. A. 1997. Hemispheric snow cover and surface albedo for model validation. Ann. Glaciol., 25 (see paper in this volume).

Romanov, I. P. 1993. Allaskh: morfometricheski kharakteristiki lida i snega v Arklicheskom basseyine (Allas of morphometric characteristics of ice and snow in the Arctic Basin). St.Petersburg, Russia, privately published.

Rothrock, D. A. and others. 1995. Polar Exchange at the Sea Surface (POLES) progress report. Seattle, WA, University of Washington. NASA Grant NAGW 2407.

Schweiger, A.J., M. C. Serreze and J. R. Key. 1993. Arctic sea ice albedo: a comparison of two satellite-derived data sets. Geophys. Res. Lelt., 20 (1), $41-44$.

Tait, A. and R. Armstrong. 1996. Evaluation of SSMR satellite-derived snow depth using ground based observations. Int. \% Remote Sensing, $17(4), 657-665$.

Vavrus, S.J. 1995. The sensitivity of the Arctic climate to leads in a coupled atmosphere-mixed-layer ocean model. J. Climate, 8 2), 158171.

Walker, A. E. and B. E. Goodison. 1993. Discrimination of a wet snowcover using passive microwave satellite data. Ann. Glaciol., 17, 307-311.

Walsh, J. E., A. Lynch, W. Chapman and D. Musgrave. 1993. A regional model for studies of atmosphere ice ocean interaction in the western Arctic. Meteorol. Almos. Phys., 51 (3-4), $179-194$.

Williams, J. 1975. The influence of snow cover on the atmospheric circulation and its role in climatic change: an analysis based on results from the NCAR global circulation model. 7. Appl. Meteorol., 14 2, 137-152.

Williams, J., R. G. Barry and W. M. Washington. 1974. Simulation of the atmospheric circulation using the NCAR global circulation model with ice age boundary conditions. J. Appl. Meleorol., 13 (3), 305-317.

WMO/Unesco/UNEP/ICSU. 1995. GCOS/GTOS plan for lerrestrial climate-related observalions: Version 1.0. GCOS 21. Geneva, World Meteorological Organization. (WMOTD 721, UNEP/EAPTR/95-07.) 